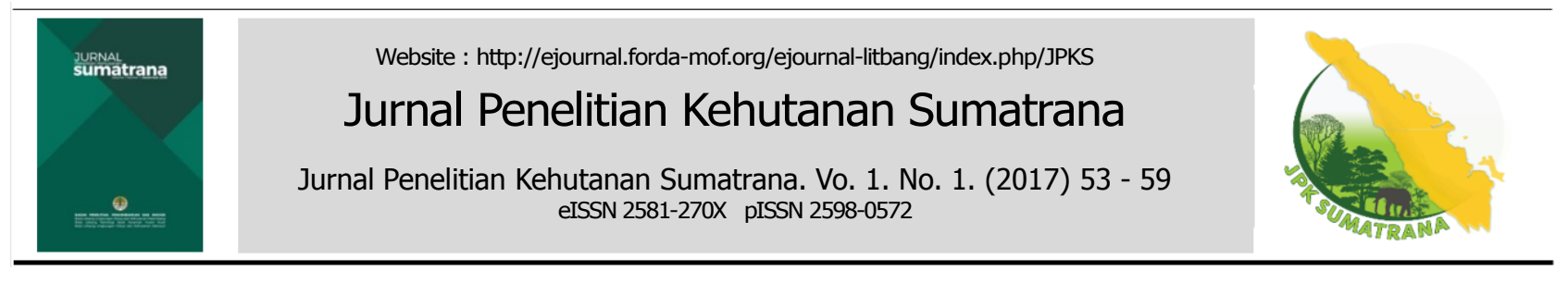

\title{
Pengaruh Suhu dan Waktu Pengempaan Terhadap Sifat Papan Serat Kerapatan Sedang Dari Kayu Mahang Dengan Perekat Asam Malat
}

\section{(Influence of Pressing Temperature and Time on The Properties of Medium Density Fibreboard from Mahang Wood with Malic Acid Adhesive)}

\author{
Agus Wahyudi ${ }^{*}$, T.A. Prayitno², Ragil Widyorini², J.P. Gentur Sutapa² \\ ${ }^{1}$ Balai Penelitian dan Pengembangan Teknologi Serat Tanaman Hutan - Kuok \\ Jln. Raya Bangkinang - Kuok km 9, Kotak Pos 4/BKN Bangkinang 28401 Riau \\ Telp. (0761) 6700911 Fax. (0761) 6700768 \\ ${ }^{2}$ Bagian Teknologi Hasil Hutan, Fakultas Kehutanan UGM Yogyakarta \\ Jln. Agro No 1, Bulaksumur, Sleman - Yogyakarta \\ *Email: agus.kuok@gmail.com
}

\author{
Article History: \\ Received 6 March 2017; Received in revised form 25 Agust 2017; \\ Accepted 25 Agust 2017; Available online since 30 Sept 2017
}

\begin{abstract}
ABSTRAK
Penggunaan asam malat sebagai agen pengikat alami masih relatif sedikit. Oleh karena itu penelitian ini difokuskan pada pengaruh suhu dan lama waktu pengempaan terhadap sifat papan serat kerapatan sedang dari campuran serat kayu mahang $90 \%$ dan serat bambu petung $10 \%$ dengan kadar perekat asam malat $25 \%$. Faktor pada penelitian ini adalah suhu pengempaan $140^{\circ} \mathrm{C}, 160^{\circ} \mathrm{C}$ dan $180^{\circ} \mathrm{C}$ serta lama waktu pengempaan yang diberikan 10 menit dan 15 menit. Sifat fisika dan mekanika papan serat diuji berdasarkan standart pengujian JIS A 5905. Peningkatan suhu dan lama waktu pengempaan memperlihatkan kenaikan sifat fisika dan mekanika papan serat yang dihasilkan. Kualitas papan serat optimum diperoleh pada kondisi suhu pengempaan $180^{\circ} \mathrm{C}$ selama 15 menit dengan nilai pengembangan tebal 2,44\%, penyerapan air 51,23\%, kekuatan rekat internal 0,71 $\mathrm{MPa}$, keteguhan patah 9,21 MPa dan keteguhan elastisitas 2,65 $\mathrm{GPa}$.
\end{abstract}

Kata kunci: Papan serat, kayu mahang, bambu petung, agen pengikat alami, asam malat

\begin{abstract}
The use of malic acid as a natural binding agent is still relatively limited. Therefore, this study focused on the effect of pressing temperature and time on properties of medium density fiberboard from a mixture of $90 \%$ fibers mahang wood and $10 \%$ fibers bamboo petung with malic acid adhesive content $25 \%$. Factors in this study is the pressing temperature of $140^{\circ} \mathrm{C}, 160^{\circ} \mathrm{C}$ and $180^{\circ} \mathrm{C}$ and a long pressing time given 10 minutes and 15 minutes. The properties of physics and mechanics fiberboard tested by testing standard JIS A 5905. The increase in the pressing temperature and time showed of physical and mechanical properties of fiberboard. Quality fiberboard optimum pressing temperature conditions obtained at $180^{\circ} \mathrm{C}$ for 15 minutes with a value of thickness swelling $2.44 \%$, water absorption $51.23 \%$, internal bonding 0.71 MPa, modulus of repture 9,21 MPa and modulus of elasticity 2,65 GPa.
\end{abstract}

Keywords: Fibreboards, mahang wood, bamboo petung, natural binding agent, malic acid

\section{PENDAHULUAN}

Mahang (Macaranga sp) adalah salah satu jenis tanaman pioner yang tumbuh di lahan mineral dan gambut pada hutan sekunder. Menurut data Kementerian Kehutanan tahun 2013, luas hutan sekunder 
di Indonesia yang berada di dalam kawasan hutan mencapai 40,82 juta ha dan 1,82 juta ha berada di Provinsi Riau (Anonim, 2014). Kayu mahang belum banyak dimanfaatkan oleh masyarakat di Provinsi Riau karena berbagai sebab, seperti kayunya yang ringan, kurang kuat dan tidak awet (Sutisna et al., 2004). Pemanfaatannya masih sebatas sebagai kayu papan untuk bahan pembuatan peti bibit tanaman/buah dan papan cetakan dalam pengecoran bangunan. Salah satu upaya untuk meningkatkan nilai tambah kayu mahang melalui sentuhan teknologi menjadi produk papan panel berupa papan serat.

Papan serat kerapatan sedang atau Medium Density Fibreboard (MDF) merupakan salah satu jenis produk panel kayu yang dibuat dari bahan-bahan berlignoselulosa, khususnya kayu. Dalam pembuatan papan MDF, bahan baku yang digunakan dapat berasal dari serat berbagai jenis kayu atau limbah berbahan lignoselulosa ditambah bahan perekat untuk menyatukan ikatan antar serat (Xing et al., 2007). Bahan perekat yang umumnya digunakan adalah urea formaldehida (UF), phenol formaldehida (PF) dan melamin formaldehida (MF) tergantung dari tujuan akhir penggunaan papan serat. Perekat UF paling banyak digunakan dalam pembuatan papan serat karena harganya yang relatif murah, tidak berwarna dan jumlah perekat yang dibutuhkan sekitar 8-15\%.

Produk papan MDF dengan bahan perekat berbasis formaldehida menyisakan permasalahan yaitu adanya emisi formaldehida di dalam proses dan produknya. Senyawa formaldehida dapat menyebabkan kanker, iritasi pada mata dan kerongkongan serta gangguan pernapasan (Roffael, 1993). Selain itu UF, MF, PF, serta isosianat merupakan perekat yang menggunakan bahan baku turunan minyak bumi sehingga tidak ramah terhadap lingkungan.

Permasalahan emisi formaldehida yang dihasilkan di dalam proses pembuatan dan produk komposit dengan perekat berbasis formaldehida menjadi dasar dilakukannya penelitian dan pengembangan produk komposit berbasis perekat alam atau bahkan tanpa perekat (Xu et al., 2003; Okuda \& Sato, 2006; Widyorini et l., 2005, 2013). Penggunaan beberapa perekat alami agar performa ikatannya baik harus ditambahkan bahan kimia dari turunan minyak bumi yang tidak ramah lingkungan, bahkan ada beberapa bahan kimia tersebut berbahaya bagi kesehatan (Yang et al., 2006; Mansouri et al., 2007; Krug \& Tobisch, 2010; Hoong et al., 2011). Kelemahan produk komposit dengan perekat alam atau tanpa perekat adalah kestabilan dimensi yang relatif rendah dan sangat tergantung pada karakteristik kimia bahan baku (Widyorini et al., 2015). Oleh sebab itu, perlu dilakukan inovasi penggunaan perekat alami sebagai perekat dalam pembuatan papan komposit. Perekat alami yang mulai dikembangkan adalah asam polikarboksilat yaitu asam sitrat (Umemura et al., 2012; 2013; Widyorini et al., 2013; 2015). Selain asam sitrat, asam malat termasuk juga salah satu jenis asam polikarboksilat yang mempunyai sifat titik lebur pada suhu $130^{\circ} \mathrm{C}$ dan titik penguraian termal pada suhu $185^{\circ} \mathrm{C}$ (Sugawara et al., 2014). Untuk mengetahui kondisi yang paling optimum penggunaan asam malat sebagai perakat alami dalam pembuatan papan serat dari campuran serat pulp kayu mahang dan serat pulp bambu petung, maka perlu dilakukan penelitian pengaruh suhu dan waktu pengempaan dalam pembuatan papan MDF dari campuran kayu mahang dan bambu petung.

\section{BAHAN DAN METODE}

\section{A. Bahan}

Bahan yang digunakan dalam penelitian ini adalah kayu mahang, bambu petung, asam malat anhidrat dan aquades. Asam malat dilarutkan dalam aquades dengan kelarutan $50 \%$ berbasis berat sebagai bahan perekat papan serat.

\section{B. Metode}

1. Persiapan serat kayu mahang dan bambu petung

Sampel kayu mahang dan bambu petung dibuat chip dengan ukuran $3 \times 1 \times 0,1$ $\mathrm{cm}$, sampel bambu petung dan kayu mahang bagian kulit dibuang, ruas dan bagian dalam bambu petung juga dibuang. Pembuatan 
pulp kayu mahang dan bambu petung dilakukan dengan proses termomekanis dengan suhu steam $100^{\circ} \mathrm{C}$, jarak antar cakram disk refiner dibuat sebesar $0,25 \mathrm{~mm}$. Serat pulp kayu mahang dan bambu petung kemudian dikeringanginkan sampai mencapai kering udara.

\section{Pembuatan papan serat}

Pembuatan papan serat dilakukan dengan proses kering dengan target kerapatan $0,7 \mathrm{~g} / \mathrm{cm}^{3}$. Campuran serat pulp kayu mahang dan bambu petung (90/10\% w/w) yang sudah kering udara (kadar air : 6$8 \%$ ) kemudian dicampur dengan larutan asam malat sebanyak $25 \%$ berdasarkan berat kering udara bahan serat. Bahan campuran serat kayu mahang, serat bambu petung dan larutan asam malat tersebut kemudian dioven selama \pm 24 jam sampai diperoleh kadar air sekitar 2-5\%. Bahan serat kemudian dibuat mat ukuran $25 \times 25$ $\mathrm{cm}$, target ketebalan $0,7 \mathrm{~cm}$ dan kerapatan $0,7 \mathrm{~g} / \mathrm{cm}^{3}$ dengan kondisi pengempaan sesuai perlakuan. Papan setiap perlakuan dibuat sebanyak 3 ulangan sehingga papan yang dibuat sebanyak 18 papan.

\section{Pengujian papan serat}

Setelah proses pengempaan, papan serat dikondisikan sampai mencapai kondisi kering udara (7-14 hari) kemudian diuji baik sifat fisis (kerapatan, pengembangan tebal dan penyerapan air setelah perendaman 24 jam pada air kondisi ruangan), maupun sifat mekanis (kekuatan rekat internal, modulus patah dan modulus elastisitas) sesuai dengan prosedur pengujian Japanese Industrial Standard JIS A 5905 fibreboards (Japan Standard Association, 2003). Contoh uji untuk pengujian pengembangan tebal dan penyerapan air berukuran $5 \times 5 \mathrm{~cm}$, modulus patah dan modulus elastisitas menggunakan sampel berukuran $20 \times 5 \mathrm{~cm}$, serta kekuatan rekat internal berukuran $5 \mathrm{x}$ $5 \mathrm{~cm}$.

\section{Analisis Data}

Rancangan penelitian menggunakan faktorial dalam rancangan acak lengkap. Faktor pertama adalah suhu pengempaan $\left(140^{\circ} \mathrm{C}, 160^{\circ} \mathrm{C}\right.$ dan $\left.180^{\circ} \mathrm{C}\right)$, dan faktor kedua adalah waktu kempa (10 menit dan 15 menit). Data pengamatan sifat fisis dan mekanis yang diperoleh dianalisis dengan uji F (ANOVA). Apabila hasil uji F berbeda nyata maka dilanjutkan dengan uji jarak berganda Duncan.

\section{HASIL DAN PEMBAHASAN}

Papan serat kerapatan sedang dari campuran serat pulp kayu mahang dan serat pulp bambu petung ( 90/10 $5 \mathrm{w} / \mathrm{w}$ ) dengan perekat asam malat $25 \%$ dibuat pada beberapa kondisi suhu dan waktu pengempaan menghasilkan papan serat yang berwarna kecoklatan dan kompak/tidak mudah terurai. Tabel 1, menunjukkan perlakuan suhu pengempaan berpengaruh nyata pada taraf uji 0,01 terhadap seluruh sifat fisika dan mekanika papan serat yang dihasilkan. Sedangkan waktu pengempaan berbengaruh nyata pada taraf uji 0,01 terhadap sifat pengembangan tebal, penyerapan air dan keteguhan rekat internal, serta berpengaruh nyata pada taraf uji 0,05 terhadap keteguhan patah namun tidak berpengaruh nyata terhadap nilai keteguhan elastisitas. Faktor interaksi suhu dan waktu pengempaan tidak berpengaruh nyata terhadap sifat keteguhan elastisitas, namun sifat fisika dan mekanika lainnya berpengaruh nyata pada taraf uji 0,01 dan 0,05 .

Gambar 1 dan Gambar 2 menunjukkan penyerapan air dan pengembangan tebal papan serat kerapatan sedang dari campuran kayu mahang dan bambu petung pada berbagai kondisi suhu dan lama waktu pengempaan. Semakin tinggi suhu dan lama waktu pengempaan mampu memperbaiki sifat penyerapan air dan pengembangan tebal papan serat. Nilai penyerapan air papan serat masih cukup tinggi pada semua kondisi yaitu berkisar 51,23-61,72\%, sedangkan pengembangan tebalnya rendah yaitu maksimal 6,62\%.

Semua papan serat yang dibuat pada berbagai kondisi suhu dan lama waktu pengempaan memenuhi standart JIS A 5905 yaitu nilai pengembangan tebalnya kurang dari $12 \%$. Nilai pengembangan tebal papan serat yang dibuat pada suhu kempa $180^{\circ} \mathrm{C}$ memiliki nilai hampir 2 kali lebih rendah dari suhu pengempaan $140^{\circ} \mathrm{C}$. Stabilitas dimensi 
papan serat meningkat seiring dengan meningkatnya suhu pengempaan disebabkan adanya degradasi hemiselulosa sehingga mengurangi sifat higroskopi bahan serat. Menurut Sekino et al. (1999) fenomena rendahnya sifat higroskopi kerena adanya perubahan kandungan hemiselulosa selama perlakuan panas, merupakan salah satu faktor untuk meningkatkan sifat stabilitas dimensi bahan. Selain adanya degradasi hemiselulosa, reaksi ikatan silang antara asam polikarboksilat (asam malat) dengan gugus hidroksi bahan mengurangi sifat higroskopi kayu (Rowell et al., 1988 in Vukusic et al., 2006).

Gambar 3 menunjukkan sifat keteguhan rekat internal papan serat pada berbagai kondisi suhu dan lama waktu pengempaan. Nilai keteguhan rekat internal papan meningkat seiring dengan meningkatnya suhu dan lama waktu pengempaan yang diberikan. Keteguhan rekat internal papan serat pada suhu kempa $140^{\circ} \mathrm{C}$ selama 10 menit dan 15 menit berturut-turut $0,24 \mathrm{MPa}$ dan $0,34 \mathrm{MPa}$ sedangkan pada suhu kempa $180^{\circ} \mathrm{C}$ nilai keteguhan rekat internalnya menjadi 0,70 $\mathrm{MPa}$ dan $0,71 \mathrm{MPa}$, terjadi peningkatan hampir 2-3 kali lipat. Hal ini menunjukkan bahwa asam malat dapat berfungsi sebagai agen pengikat seperti asam sitrat dalam penelitian Umemura et al. (2012) pada produk komposit dari kayu dan kulit akasia.

Tabel 1. Rekapitulasi hasil ANOVA

Tabel 1. Recapitulation of ANOVA report

\begin{tabular}{lccc}
\hline $\begin{array}{l}\text { Parameter } \\
\text { (Parameters) }\end{array}$ & $\begin{array}{c}\text { Suhu kempa } \\
\text { (Press temperature) }\end{array}$ & $\begin{array}{l}\text { Waktu kempa } \\
\text { (Press time) }\end{array}$ & $\begin{array}{c}\text { Interaksi } \\
\text { (Interaction) }\end{array}$ \\
\hline Pengembangan tebal & $<0,01^{* *}$ & $<0,01^{* *}$ & $0.04^{*}$ \\
Penyerapan air & $<0,01^{* *}$ & $<0,01^{* *}$ & $<0,01^{* *}$ \\
keteguhan patah & $<0,01^{* *}$ & $0,03^{*}$ & $0.03^{*}$ \\
Keteguhan elastisitas & $<0,01^{* *}$ & $0,08 \mathrm{~ns}$ & $0.32 \mathrm{~ns}$ \\
Kekuatan rekat internal & $<0,01^{* *}$ & $<0,01^{* *}$ & $0.03^{*}$ \\
\hline
\end{tabular}

Keterangan: * berbeda nyata taraf uji $5 \%, * *$ berbeda nyata taraf uji $1 \%$, ns tidak berbeda nyata Remarks: * significant differences at 5\%, significant differences at 1\%, ns no significant differences

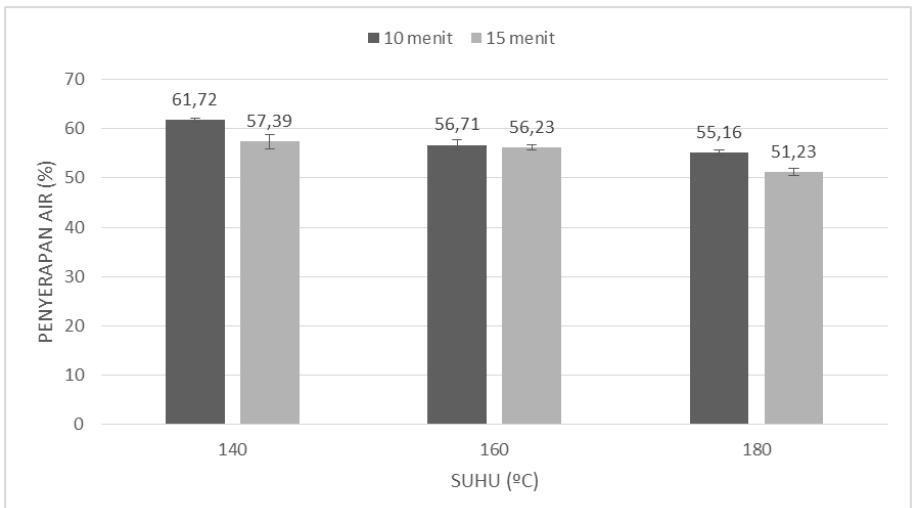

Gambar 1. Penyerapan air papan serat kayu mahang pada beberapa kondisi suhu dan waktu pengempaan

Figure 1. Water absorption of fibreboards from mahang wood on some pressing temperature and time

Menurut Umemura et al. (2012) hasil analisis FTIR memperlihatkan bahwa terbentuk ikatan ester yang terjadi dari gugus karboksil pada asam sitrat dan gugus hidroksil pada kayu. Ikatan ester tersebut yang menyebabkan terjadinya peningkatan kekuatan rekat internal pada papan. Suhu pengempaan yang diberikan selama perlakuan membantu terbentuknya ikatan ester antara gugus karboksil dari asam malat dengan gugus hidroksil dari kayu (McSweeny et al., 2006). 


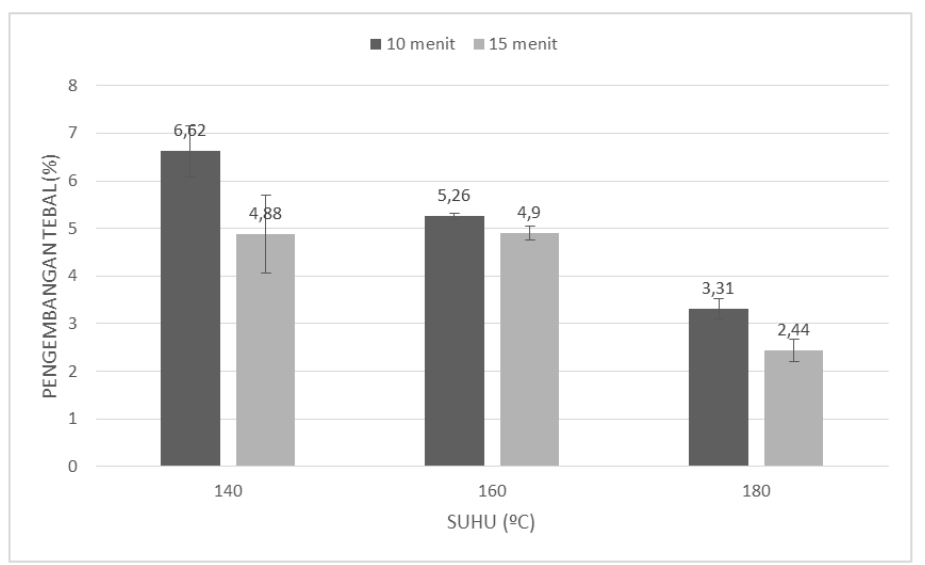

Gambar 2. Pengembangan tebal papan serat kayu mahang pada beberapa kondisi suhu dan waktu pengempaan

Figure 2. Thickness swelling of fibreboards from mahang wood on some pressing temperature and time

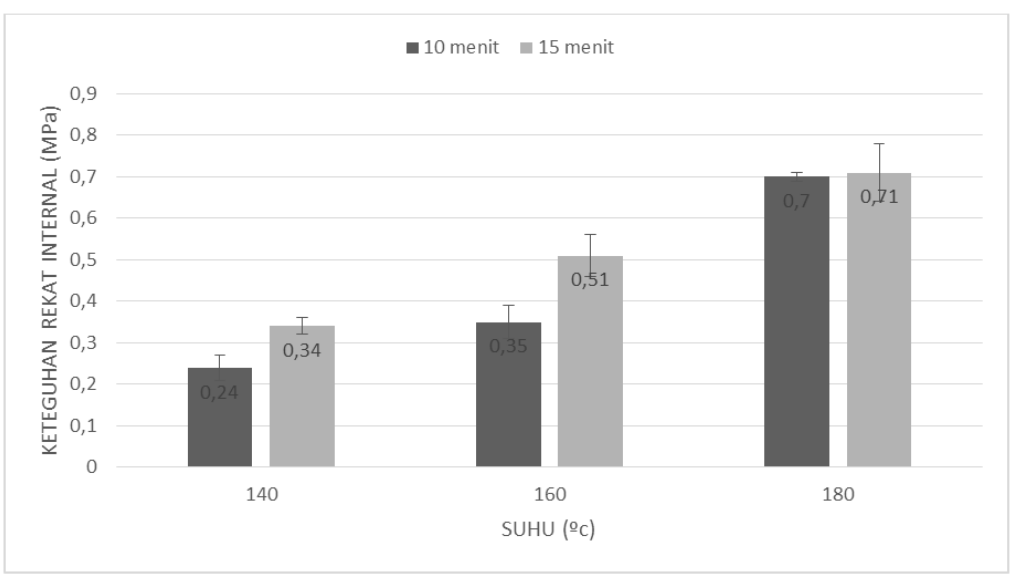

Gambar 3. Keteguhan rekat internal papan serat kayu mahang pada beberapa kondisi suhu dan waktu pengempaan

Figure 3. Internal bonding of fibreboards from mahang wood on some pressing temperature and time

Nilai sifat mekanis papan serat dari campuran kayu mahang dan bambu petung dengan perekat asam malat 25\% pada berbagai kondisi suhu dan lama waktu pengempaan ditunjukkan dalam Gambar 4 dan Gambar 5. Sifat mekanis papan menunjukkan peningkatan seiring dengan meningkatnya suhu dan lama waktu pengempaan.

Keteguhan elastis papan serat dengan suhu kempa $140^{\circ} \mathrm{C}, 160^{\circ} \mathrm{C}$ dan $180^{\circ} \mathrm{C}$ dengan lama waktu 10 menit berturut-turut 1,3 GPa, 1,73 GPa dan 2,51 GPa. Sifat keteguhan elastis papan mengalami peningkatan dengan adanya peningkatan suhu kempa, namun lama waktu pengempaan tidak menunjukkan perbedaan terhadap nilai keteguhan elastis papan. Nilai keteguhan patah dan keteguhan elastis papan serat yang dikempa dengan suhu $180^{\circ} \mathrm{C}$ meningkat hampir 2 kali dibandingkan dengan suhu kempa $140^{\circ} \mathrm{C}$. Menurut McSweeny et al. (2006) suhu pengempaan yang diberikan selama perlakuan membantu terbentuknya ikatan ester antara gugus karboksil dari asam malat dengan gugus hidroksil dari kayu (McSweeny et al., 2006), sehingga nilai keteguhan rekat internal papan meningkat mengakibatkan nilai $\mathrm{MOE}$ dan MOR papan juga meningkat. 


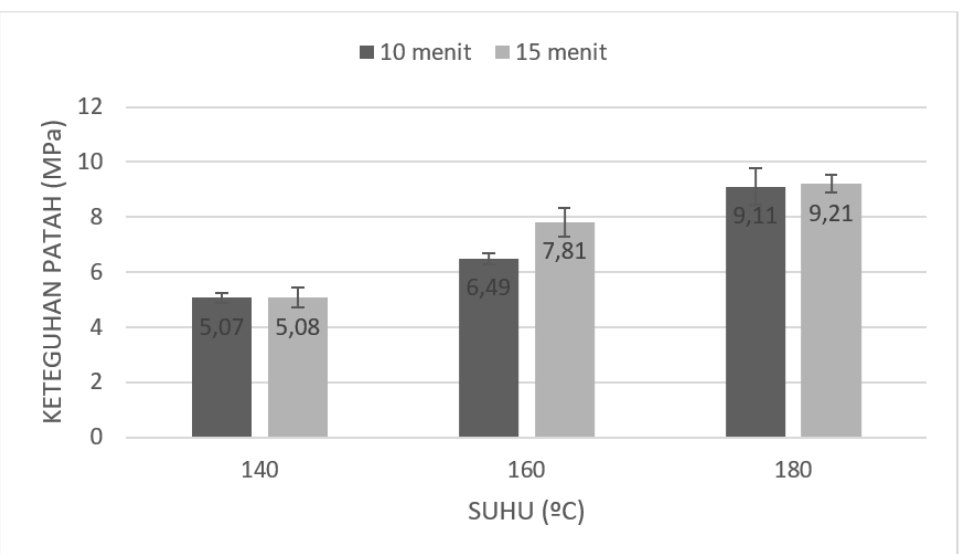

Gambar 4. Keteguhan patah papan serat kayu mahang pada beberapa kondisi suhu dan waktu pengempaan

Figure 4. Modulus of rupture of fibreboards from mahang wood on some pressing temperature and time

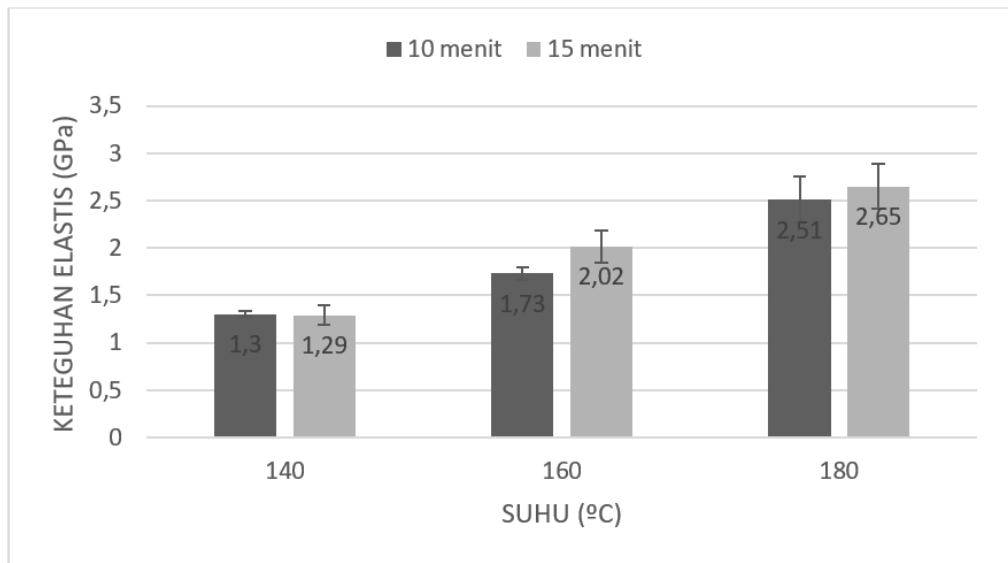

Gambar 5. Keteguhan elastis papan serat kayu mahang pada beberapa kondisi suhu dan waktu pengempaan

Figure 5. Modulus of elastisity of fibreboards from mahang wood on some pressing temperature and time

\section{KESIMPULAN}

Sifat fisika dan mekanika papan serat kerapatan sedang dari campuran $90 \%$ serat kayu mahang dan $10 \%$ serat bambu petung menggunakan perekat asam malat sebesar $25 \%$ semakin meningkat seiring dengan peningkatan suhu dan lama waktu pengempaan yang diberikan. Kondisi optimum pada penelitian ini adalah pengempaan dengan suhu $180^{\circ} \mathrm{C}$ selama 15 menit. Pada kondisi tersebut, papan serat memiliki nilai pengembangan tebal $2,44 \%$, penyerapan air 51,23\%, keteguhan rekat internal 0,71 MPa, keteguhan patah 9,21 MPa dan keteguhan elastisitas 2,65 GPa. Semua nilai tersebut dapat memenuhi standart JIS A
5905 tipe 30, hanya nilai keteguhan patah yang tidak masuk tipe tersebut namun masuk dalam standart JIS A 5905 tipe 5.

\section{UCAPAN TERIMA KASIH}

Penulis mengucapkan terima kasih kepada Eko Sutrisno, SP dan Andi Mandala Putra atas bantuannya dalam pembuatan serat pulp termomekanik kayu mahang dan bambu petung.

\section{DAFTAR PUSTAKA}

Anonim (2014) Statistik kementerian kehutanan 2013. Kementerian 
Kehutanan. Jakarta.

Hoong, YB., MT. Paridah, YF. Loh, H. Jalaludin, and LA. Chuah (2011). A new source of natural adhesive: Acacia mangium bark extracts co polymerized with phenol formaldehyde for bonding Mempisang (Annonaceae spp) veneer. Intr J Adhes (31) 164-167.

Japanese Standard Association. (2003). Japanese Industrial Standard for Fiberboards A 5905. Japanese Standard Association. Tokyo.

Krug, D., and S. Tobisch (2010). Use of proteins as binders for wood based panel. Eur J Wood Prod (68). 289-301

Okuda, N and M. Sato. (2006). Water resistance properties of kenaf core binderless boards. Journal of Wood Science(52), 422-428.

Roffael, E. (1993) Formaldehyde release from particle board and other wood based panels. Kuala Lumpur: FRIM Kepong.

Sekino, N., M. Inoue, M. Irle and T. Adcock. (1999). The mechanism behind the improved dimensional stability of particleboards made from steam pretreatment particles. Holzforschung (53) 435-440.

Sugawara, R and K. Umemura (2014). Bonding composition and board. United States Patent. No. US 2014/0011042 A1.

Sutisna, U., M. Wardani, T. Kalima, Y.I. Mandang, N. Hadjib, G. Pari, G. Sumarni, S. Abdurrohim, Barly, M.I. Iskandar, O. Rachman, E. Basri, Y. Lisnawati (2004). Atlas Kayu Indonesia Jilid III. Puslitbang Teknologi Hasil Hutan. Bogor.

McSweeny JD, RM. Rowell andS. Min. (2006). Effect of citric acids modification of aspen wood on sorption of copper ion. Journal of Natural Fibers, 3(1), 43-58.

Mansouri, NE El., A. Pizzi, and J. Salvado (2007). Lignin based polycondensation resins for wood adhesive. J. Appl Polym Sci. (103) 1690-1699
Umemura, K., T. Ueda, SS. Munawar and S. Kawai. (2012). Application of citric acid as natural adhesive for wood. Journal of Applied Polymer Science (123), 19911996.

Umemura, K., O. Sugihara, and S. Kawai (2013). Investigation of a new natural adhesive composed of citric acid and sucrose for particleboard. J Wood Sci. (59), 203-209.

Vukusic SB., D. Katovic, C. Schramm, J. Trajkovic and B. Sefc. (2006). Polycarboxylic acids as non formaldehyde anti swelling agents for wood. Holzforschung(60), 439-444.

Widyorini, R., T. Higashihara, J. Xu, T. Watanabe and S. Kawai. (2005). Self bonding characteristics of binderless kenaf core composite. Wood and Science Technology (39), 651-662.

Widyorini, R., AP. Yudha, Y. Adifandi, K. Umemura and S. Kawai. (2013). Characteristics of bamboo particleboard bonded with citric acid. Wood Research Journal 4 (1).31-35.

Widyorini, R., AP. Yudha, G. Lukmandaru dan TA. Prayitno. (2015). Sifat fisika mekanika dan ketahanan papan partikel bambu dengan perekat asam sitrat terhadap serangan rayap kayu kering. Jurnal Ilmu Kehutanan Vol. 9 (1). 12-22.

Xu, J., G. Han and S. Kawai. (2003). Develompment of binderless particleboards from kenaf core using steam injection pressing. Journal of Wood Science (49). 327-332.

Xing, C., J. Deng, and SY. Zhang (2007) Effect of thermo mechanical refining on properties of MDF made from black spruce bark. Wood Sci Technol (41). 329-338.

Yang, I., M. Kuo, DJ. Myers and A. Pu. (2006). Comparation of protein based adhesive resins for wood composites. J Wood Sci. (52). 503-508. 